THE WHOLE JOURNEY 



\title{
THE WHOLE JOURNEY
}

\section{SHAKESPEARE'S POWER \\ OF DEVELOPMENT}

\author{
C. L. BARBER \\ AND \\ RichaRd P. WheEler
}

University of California Press

Berkeley

Los Angeles

London 
University of California Press

Berkeley and Los Angeles, Califomia

University of California Press, Ltd.

London, England

(C) 1986 by

The Regents of the University of California

Library of Congress Cataloging-in-Publication Data

Barber, C. L. (Cesar Lombardi)

The whole journey.

Includes index.

1. Shakespeare, William, 1564-1616-Criticism and interpretation-Addresses, essays, lectures.

I. Wheeler, Richard P. (Richard Paul), 1943-

II. Title.

$\begin{array}{llll}\text { PR2976.0324 } & 1986 & 822.3^{\prime} 3 & 85-20712\end{array}$

ISBN 0-520-05432-6 (alk. paper)

Printed in the United States of America

123456789 
For Cleo H. Barber 

One of the greatest capacities of genius is the power of development. . . . As with Shakespeare, his later work must be understood through the earlier, and the first through the last; it is the whole journey, not any one stage of it, that assures him his place among the great.

T. S. Eliot on James Joyce 
